\title{
Vi Capsular Polysaccharide Typhoid Vaccine
}

National Cancer Institute

\section{Source}

National Cancer Institute. Vi Capsular Polysaccharide Typhoid Vaccine. NCI Thesaurus.

Code C97127.

A live attenuated bacteria injectable vaccine used to prevent typhoid, which is caused by Salmonella typhi. 